\title{
Role of Economic Policies in Protecting the Environment: The Experience of Pakistan
}

\author{
RASHID FARUQEE
}

\begin{abstract}
Economic policies that ensure efficient allocation of resources is a necessary, but not a sufficient condition for creating appropriate environmental incentives. Environment-specific policies are also needed to correct market failures leading to environment problems. Two types of policies can be used to deal with environmental problems-command and control policies and incentive- or market-based policies. Command and control policies involve government mandating of environmental quality standards on emissions, technology type, or input use. Incentive- or market-based policies use prices to try to affect pollution and resource use. Despite the advantages of marketbased approaches, Pakistan, like many other countries, mostly followed control policies. But these policies have often failed to achieve results because regulating institutions lack the financial and technical resources to implement these policies effectively.

Pakistan's brown environmental problems include industrial waste water pollution, domestic waste water pollution, motor vehicle emissions, urban and industrial air pollution, and marine and coastal zone pollution. Economic policy failures are contributing significantly to many of these problems.

Green environmental problems affect irrigated agriculture, rainfed agriculture, forests, and rangelands. In irrigated agriculture, economic policies, such as subsidies on irrigation water, have provided incentives for farmers to over use water in their production practices, thereby exacerbating the problem of waterlogging and salinity. Deforestation and rangeland degradation have resulted, in part, due to lack of property rights in communal forests and lack of incentive for local communities to participate in forest management decisions.
\end{abstract}

\section{ECONOMIC POLICIES AND THE ENVIRONMENT}

Like most developing countries, Pakistan faces serious environmental problems. Rapid population growth (averaged about 3 percent a year since the early 1970s) and impressive GDP growth (of about 6 percent a year) have put enormous pressure on the country's natural resource base and have significantly increased levels of pollution. Rapid expansion in industrial production and urbanisation have

Rashid Faruqee is Principal Economist at the Agriculture and Natural Resource Division of the World Bank, Washington, D. C.

Author's Note: This paper is based on a World Bank gray-cover report, "Pakistan: Economic Policies, Institutions, and the Environment”, December 15, 1996. The World Bank report was prepared by Rashid Faruqee and Jonathan Coleman, in consultation with Pakistani policy-makers and experts. Background papers for the World Bank report were contributed by Derek Byerlee, and Pakistani consultants, Laiq Ali, Vaqar Zakaria, and Akmal Siddiq. 
led to increased levels of waste water pollution, solid waste, and vehicle emissions that have resulted in serious health problems in many areas of the country.

Soil erosion and salinity have caused crop yields to decline in some areas on what were previously some of the most productive soils in Pakistan. Forests are being depleted, especially in the Northern areas, as land is cleared for livestock fodder and fuelwood. Rangelands are increasingly becoming degraded, some irreversibly, and the marine environment has been affected by industrial pollutants and increasing levels of salinity as a result of upstream irrigation. A recent study Brandon (1995) attempts to value environmental costs in Pakistan and puts the estimate of environmental damage at \$1 billion to 2.1 billion per year, or 2.6 to 5.0 percent of GDP in 1992 values.

In response to environmental concerns, the government of Pakistan prepared its National Conservation Strategy (NCS) in March 1992. The NCS has been useful, especially in raising awareness of environmental problems among government institutions. Following the release of the report several institutional improvements were made, among them the establishment of an NCS implementation unit in the Environment and Urban Affairs Division (EUAD) and the creation of an Environmental Section, mandated to integrate environmental concerns in economic development planning, in the Planning Commission. The Sustainable Development Policy Institute (SDPI) was set up on the basis of NCS recommendations to provide economic and policy analysis for sustainable economic development, and most of the provinces have created environmental cells in their Planning and Development (P\&D) Departments in order to screen investment projects for their effects on the environment.

Following early successes in implementing the NCS, however, progress now appears to be faltering because of several major factors. First, not enough attention has been given to government policies that provide incentives for individuals to pollute the environment and exploit natural resources in an unsustainable manner. Second, institutions set up for managing the environment, such as the EPAs, appear to be weak and incapable of implementing an appropriate environmental strategy or coordinating the actions of donors to help protect the environment. Third, the goals set by the NCS may have been overambitious given technical, economic, and institutional constraints Pakistan faces. Fourth, the role of the private and nongovernmental (NGO) sectors has not been defined. Finally, many attributed slow progress to a lack of political commitment to sustainable environmental improvement.

Broadly speaking, there are two ways of protecting (improving) the environment-policies and regulations. Policies can be general (economy-wide) with impacts on the environment, or specific, directed policies to aimed at environmental protection. This paper assesses how economic policies (and in some 
cases the absence of economic policies) have affected the environment in Pakistan. This should help in assessing what policies or areas warrant special attention to improve environmental protection.

The paper focuses on both brown and green issues, examining problems affecting water pollution (domestic and human waste water, industrial waste water discharge); air pollution (vehicle emissions, urban air pollution, industrial emissions); and marine and coastal zones; irrigated and rainfed agriculture; forests; and rangeland.

\section{Economic and Demographic Causes of Environmental Problems}

Environmental problems are caused by a variety of economic and demographic factors, including market failures, policy failures, poverty, and population growth, all of which have been important in Pakistan.

\section{Policy and Market Failures}

Environmental problems are often caused or exacerbated by inappropriate policies that provide incentives for practices detrimental to the country's natural resource base. In Pakistan, for example, subsidies on some agricultural inputs have caused damage to the environment. Especially damaging has been the provision of irrigation water at prices substantially below the cost of delivery, a policy that has increased waterlogging, led to the loss of many mangrove forests in the coastal areas, and diminished biodiversity (NCS). The former policy of subsidising agricultural chemicals led to excessive use of pesticides. The policy of providing energy (such as electricity and diesel) at below-market price provides incentives to individuals to overuse the natural resource base.

Environmental problems often arise because decisions about natural resource use and pollution are made without taking into account the full costs of environmental damage to society at large. Market mechanisms sometimes fail to allocate natural resources efficiently or to reflect the social value of the environment. Many of the green environmental problems in Pakistan reflect market failures associated with open access or common property resources.

Markets also fail when there is a market for some but not other uses for a resource. Deforestation in some areas of Pakistan, for example, has occurred because the nonmarket benefits of soil conservation have frequently been ignored.

\section{Poverty and Population Growth}

Poverty and population growth have contributed to the degradation of the environment in Pakistan, where they have caused soil degradation, deforestation, 
rangeland degradation, marine and coastal zone damage, and many forms of urban and industrial pollution.

Poverty and environmental degradation are closely connected because poor farmers face very high production and financial risks, often the result of misguided policy interventions in factor and product markets or insecure land tenure.

Of course, the cause and effect relationship between poverty and the environment works in both directions. A poor and fragile environment can be a major cause of poverty. Agricultural productivity on severely eroded or waterlogged soils is generally low; as forests become depleted, labour productivity declines as more time is spent collecting fuelwood. In addition, environmentally induced health problems, such as intestinal diseases from unsafe drinking water, disproportionally reduce the working capacity and productivity of poor labourers. Health expenditures increase as a result of environmentally induced diseases, and the costs of cleaning up and preserving environmentally damaged areas can be substantial.

Population growth also contributes to environmental degradation. Construction of housing and infrastructure to support a growing population has had a significant effect on the environment, and migration to urban areas has increased urban pollution. Moreover, as the population increases, greater demands are placed on the productive agricultural land to meet food needs.

To prevent environmental degradation, appropriate policies and institutions must be put in place so that the true costs (both private and social) of economic activities are borne by decision-makers. Such policies and institutions include those that correct market failures, help define property rights, and provide for strong and consistent enforcement of regulations. Institutions must be flexible, because improvements in technology, changes in tastes, and new environmental investments mean that the relationship between development and economic growth and natural resources is constantly changing.

\section{Economy-wide Policies and the Environment}

Table 1 describes some of the economic and environmental effects of both past and present economic policies in Pakistan. The table looks at the present and past policies without making any judgment on their appropriateness. Some of these policies have been distortionary, and have adversely affected both overall economic growth and the environment.

Despite terms of trade that have heavily favoured industry, Pakistani agricultural production has increased as a result of an increase in both crop yields and area under cultivation. But some of the policies that spurred this growth have been damaging to the environment, either because they were not economically appropriate (the pricing of water, for example), or not accompanied with corrective policies for environmental protection. Irrigation of the Indus Basin, for example, has increased 
Table 1

Past and Present Economy-wide Policies and Their Effects on the Environment in Pakistan

\begin{tabular}{|c|c|c|c|}
\hline \multirow[b]{2}{*}{ Policy Area } & \multirow[b]{2}{*}{ Policy Instruments } & \multicolumn{2}{|c|}{ Outcome } \\
\hline & & Economic & Environmental $^{\mathrm{a}}$ \\
\hline $\begin{array}{l}\text { Agricultural } \\
\text { policies }\end{array}$ & $\begin{array}{l}\text { Support prices } \\
\text { Input subsidies } \\
\text { Public expenditures on agricultural } \\
\text { infrastructure }\end{array}$ & $\begin{array}{l}\text { Increased cultivable area } \\
\text { Increased crop yields } \\
\text { Increased irrigation water use } \\
\text { Increased fertiliser and chemical use }\end{array}$ & $\begin{array}{l}\text { Change in soil quality } \\
\text { Change in agricultural run-off } \\
\text { Change in rate of deforestation }\end{array}$ \\
\hline $\begin{array}{c}\text { Industrial } \\
\text { policies }\end{array}$ & $\begin{array}{l}\text { Controls on industrial imports and } \\
\text { exports of raw materials }\end{array}$ & $\begin{array}{l}\text { Increased industrial output } \\
\text { Increased energy use }\end{array}$ & $\begin{array}{l}\text { Increased industrial emission } \\
\text { Increased industrial waste water pollution }\end{array}$ \\
\hline $\begin{array}{l}\text { Trade and } \\
\text { exchange rate } \\
\text { policies }\end{array}$ & $\begin{array}{l}\text { Removal of quantitative restrictions } \\
\text { Lowering of tariffs } \\
\text { Exchange rate devaluation }\end{array}$ & $\begin{array}{l}\text { Higher returns to efficient sectors } \\
\text { (cotton, for example) } \\
\text { Changes in agricultural output pattern } \\
\text { Change in energy cost }\end{array}$ & $\begin{array}{l}\text { Change in use patterns of agricultural inputs } \\
\text { Change in land use patterns } \\
\text { Change in rate of deforestation }\end{array}$ \\
\hline Fiscal balance & $\begin{array}{l}\text { Broadened tax base } \\
\text { Reduction in agricultural input subsidies } \\
\text { Reduction in energy subsidies } \\
\text { Reduction in rural development } \\
\text { elimination of some poverty safety nets }\end{array}$ & $\begin{array}{l}\text { Increased rate of economic activity } \\
\text { Decreased agricultural input use } \\
\text { Increased energy conservation } \\
\text { Decreased research and extension } \\
\text { Increased poverty levels }\end{array}$ & $\begin{array}{l}\text { More efficient resource use } \\
\text { Lower air and water pollution levels } \\
\text { Decreased soil degradation and agricultural } \\
\text { run-off }\end{array}$ \\
\hline $\begin{array}{l}\text { Private sector } \\
\text { development }\end{array}$ & $\begin{array}{l}\text { Sale of public enterprises } \\
\text { Promotion of private sector promotion }\end{array}$ & $\begin{array}{l}\text { Increased industrial production and } \\
\text { efficiency }\end{array}$ & Change in industrial pollution \\
\hline $\begin{array}{l}\text { Redistribution of } \\
\text { income and } \\
\text { wealth }\end{array}$ & $\begin{array}{l}\text { Land reform } \\
\text { Labour protection laws } \\
\text { Social and safety net programmes }\end{array}$ & $\begin{array}{l}\text { Changes in income and consumption } \\
\text { patterns }\end{array}$ & Change in pattern of land use \\
\hline
\end{tabular}

Source: Based on Noman (1988); Shafik and Bandyopadhyay (1992); Munasinghe (1993) and World Bank (1994).

${ }^{\mathrm{a}} \mathrm{S}$ ome of these outcome assume that no corrective measures were taken. 
salinity and sodicity of the soil, and destroyed many of the riverine forests and associated flora and fauna species. The system has also led to the loss of many mangrove forests in the coastal areas and to an associated decline in biodiversity and the fishing economy. Agricultural run-off from fields to which chemicals have been applied incorrectly or inappropriately has raised the levels of toxics in the waterways. Had appropriate policies been adopted, agricultural growth could have been achieved with less damage to the environment.

Policies favouring industrialisation can have adverse effects on the environment unless measures are taken to protect the environment.

Freer international trade tends to increase investment in new technologies, which embody cleaner processes to meet higher environmental standards in countries to which Pakistan exports. This has not been significant so far, but is likely to become important in the future with trade liberalisation and more vigorous implementation of the GATT's Uruguay Round agreements on sanitary and phytosanitary standards. ${ }^{1}$ Exchange rate policies can affect the environment through the agricultural sector. Devaluation, for example, increases the prices of imported goods, and causes substitution away from imported products. Making imports more expensive, however, could reduce access to the cleaner foreign technologies by making them more costly.

Policies aimed at reducing fiscal deficit balance can affect the environment through many direct and indirect channels. Spending cuts could also have both positive and negative effects on the environment. In Pakistan, the removal of some subsidies on energy provided financial incentives to increase the efficiency of energy use, and is generally beneficial to the environment. By contrast, cuts in spending on safety net programmes for the poor will likely harm the environment, because consumption may be supplemented by increased exploitation of natural resources, including fish, rangeland, and forests.

Private sector development and policies aimed at privatising governmentowned industries may also affect the environment. During the early 1970s, many industries were nationalised in Pakistan. Nationalisation was a disaster for the environment because it led to industrial inefficiency, including the overuse of polluting technology, and provided few incentives to conserve. Reversal of this policy through privatisation with strictly enforced standards for environmental protection should prove beneficial to the environment.

${ }^{1}$ Environmentalists often argue that trade liberalisation can lead to the displacement of domestic industries, as polluting industries move across international borders to regions in which environmental regulations are less stringent. Environmentalists also claim that more open market access and international trade may force countries to reduce their production costs by lowering environmental standards. These arguments are not tenable because gains from liberalisation are generally significantly higher than the associated environmental costs, and environmental protection costs are minor determinants of comparative advantage. 
Redistribution of income and wealth has an effect on the environment. By giving ownership to farmers, land reform helps protect the environment because it enables the cost of land use to be fully borne by decision-makers and eliminates the externality that leads to overexploitation. Because the laws in Pakistan were very lax and easy to circumvent, past land reforms did not bring about the desired change in land tenure and did not have any effect on environmental protection.

\section{Incentive Policies and Institutions for Improving the Environment in Pakistan}

As noted, non-distortionary economic policies that stimulate economic growth by improving the allocation of resources generally create appropriate incentives for the protection of the environment. Such policies are referred to as "win-win" policies in that economic and environmental objectives are jointly achieved with the use of the same policy instruments. Policies for sustained development thus can build on the positive links between development and the environment.

\section{Economic Policies that Create Incentives for Improving the Environment}

The scope for policy reforms that promote income growth, poverty alleviation, and environmental improvement is very large in Pakistan. Since the 1980s and particularly in recent years, Pakistan has carried out significant structural reform of the economy. By providing economic agents with incentives to manage the natural resource base in ways that are more sustainable, market-orientated policies have generally had positive effects on the environment. These win-win policies - particularly the deregulation of prices, the privatisation of State-owned enterprises, and trade reform—should be supported and strengthened.

The structural adjustment programme eliminated many agricultural price subsidies. The subsidy on agricultural chemicals was removed, for example, and the subsidy on fertilisers is now very small. As a result, the markets for chemicals and fertilisers have become more efficient, private sector involvement in the production and distribution of these agricultural inputs has increased.

Opportunities for other win-win price policies remain unexploited. Irrigation water charges do not cover the operation and maintenance of providing service, and farmers thus receive large subsidies on water. The cheap water has provided incentives for farmers to over irrigate, leading to water wastage and severe soil degradation as a result of the leaching of nutrients from the soil. The pricing of energy is another area in which win-win opportunities are being missed. Electricity prices charged for residential users remain below the long-run marginal cost, and agricultural users pay a flat tariff instead of being charged on the basis of use. 
Subsidies also remain in the gas sector, with residential users and some industrial users paying significantly less than production costs [World Bank (1995)].

Privatisation is also a win-win policy because it can help reduce fiscal deficits - especially if proceeds from privatisation are used to reduce the government debt - and it leads to more efficient use of inputs and to the introduction of new technologies that are generally cleaner than the old ones. Private firms must be required to comply with pollution control laws and regulations; the extent to which privatisation benefits the environment thus depends on the government's monitoring and enforcement capacity. Although these capabilities are weak in Pakistan, private firms can nevertheless be encouraged to employ environment-friendly production practices through the use of market-based incentives, such as the proposed pollution tax, or through other forms of control, such as pressure from NGOs.

Rationalising the trade regime and liberalising external payments increases economy efficiency, speeds up economic growth, and reduces poverty. It is also likely to provide incentives for better natural resource management. These reforms have encouraged production of products in which Pakistan has a comparative advantage, such as cotton yarns and threads, textiles, and leather products. In some cases additional policies are required to ensure that growth in these sectors does not cause additional pollution.

Focusing only on win-win policies will not ensure sustainable resource use. An economy in which resources are allocated efficiently is a necessary not a sufficient condition for creating appropriate environmental incentives. Environment-specific policies will be needed to ensure sustainable economic development.

\section{Targeted Policies Directed at Improving the Environment}

Two types of targeted policy can be used-command and control, and incentive- or market-based policies. Within these two categories, policies can be either direct or indirect. Command and control policies involve government mandating of environmental quality standards on emissions, technology type, or input use. Incentive-based policies use prices to try to affect pollution and resource use.

Market-based approaches to regulations that mandate the behaviour of decision-makers are preferable to regulatory approaches, because policies that use economic incentives are often less costly. Taxing industrial emissions, for example, provides an incentive for firms to invest in cleaner technologies and gives firms with lower pollution abatement costs an advantage over firms with higher pollution control costs. Regulations leave these decisions to the regulators, who are rarely informed about relative costs and benefits in industry. Moreover, market-based policies that price environmental damage affect all polluters, in contrast to regulations, which affect only those firms that comply. Market-based policies send the right long-term signals to resource users, and provide polluters with an incentive 
to use technologies that are most cost effective at reducing environmental damage. Regulations that mandate standards give polluters no incentive to go beyond the regulated standard. Regulations also require monitoring and enforcement, and governments must be prepared to prosecute violators. In many developing countries, including Pakistan, the necessary monitoring and enforcement capability is weak.

\section{MAJOR BROWN PROBLEMS AND THEIR CAUSES}

Pakistan's brown environmental are serious, but there is no precise estimates of their seriousness, particularly in comparison to green problems. Brandon (1995) estimates that health impacts of water pollution is the most serious (accounts for nearly half of the total environmental damages). According to him, health impacts of air pollution accounts for nearly one-fifth of environmental damages. This section shows that many of these problems are caused by failures of policies.

\section{Industrial Waste Water Pollution}

The level of industrial pollutants emitted is growing at a very rapid pace. Indiscriminate discharge of industrial waste water is causing serious environmental problems, among them contamination of groundwater, including water drawn for drinking; contamination of sea water, affecting aquatic life and drinking water; and contamination of rivers, particularly in areas with low levels of mixing, such as harbours and estuaries. Unless policies are changed, environmental degradation as a result of industrial waste water is likely to accelerate as the manufacturing sectoralready the single largest user of commercial energy in Pakistan-continues to grow.

Much of the technology used by industry in Pakistan was acquired at a time when energy prices were artificially low and environmental impacts were not considered. Pollution from this technology is therefore higher than it is in many industrial countries. Industries with high levels of water contamination in Pakistan include textiles, leather, paper and board, sugar, fertiliser, and cement, which together account for 80 percent of total water consumed.

No comprehensive current data exist on either total industrial pollution loads or pollution intensities in Pakistan. Levels of six types of industrial pollutantstoxics, heavy metals, BOD pollutants, and suspended solid water pollutants, particulates, sulfur dioxide air pollutants-increased between six- and ten fold between 1963 and 1988, during which time GDP grew by a factor of three. This rate of growth of pollution output was above the rate of growth in India, where pollution grew at about the same rate as GDP.

Economy-wide policy distortions have contributed significantly to the problems of industrial waste water. A subsidy on energy use keeps prices below economic levels, undermining incentives for energy conservation [World Bank 
(1995)]. Pakistan is gradually moving toward a more rational system of energy pricing, which has had a positive effect on energy efficiency. Other resources, however, including water, remain underpriced, leading to inefficient use and wastage. Because access to groundwater is free and water is made available to industries at a low price, industries have very little incentive to conserve water. As a result, water usage levels are ten times higher in some industries in Pakistan than they are in industrial countries.

Targeted policies aimed at addressing industrial waste water have focused on the NEQS. To date, however, these have not been enforced. A new system, based on the "polluter pays" principle used in some industrial countries, is being discussed by the government and NGOs. Under the policy effluent charges would be imposed based on pollutant loads and the quantity of water wasted. Other potentially effective targeted policies, such as economic incentives for industries to acquire environment-friendly technology, have not been introduced.

\section{Domestic Waste Water Pollution}

Waste water in Pakistan is often dumped into open drains, streams or ponds, shallow pits, or septic tanks connected to open drains (many leading out directly to agricultural land); less often it is dumped into sewers. Household refuse is also dumped into streams and drains, which over time have become overloaded. Direct disposal of municipal waste water into streams not only reduces groundwater quality, but also disturbs the aquatic ecosystems, depletes aquatic resources, and affects agricultural uses of the surface water. Another problem is the practice of municipal waste water for farm use prior to treatment. Besides serious health dangers when consumed, soils irrigated by untreated municipal waste water become enriched in salts and quickly become unproductive for cultivation.

Only 80 percent of the urban and 45 percent of the rural population is estimated to have access to clean water in Pakistan, and migration to the cities is putting pressure on inadequate urban water and sanitation facilities. Pollution has led to the spread of water-related infections: more than 40 percent of the hospital beds in Pakistan are occupied by patients with water-related diseases, such as cholera, typhoid, hepatitis, diarrhoea, dysentery, yellow fever, and malaria, and about 60 percent of infant mortality is associated with water-related infectious and parasitic diseases.

Problems of domestic water disposal tend to stem from distortions due to economy-wide policies, failure of targeted environmental policies, and institutional failures. Uneconomic water pricing exacerbates the problem in urban areas, where a flat rate is charged or water is provided free of charge, a policy that both encourages the wasteful use of water and eliminates incentives for suppliers of water services to upgrade their water supply, treatment, and disposal facilities. In rural areas, waste 
water is used as a cheap, nutrient-rich source of supplemental irrigation, so that the need to invest in treatment facilities is not recognised. Targeted policies to control domestic waste water have not developed.

\section{Motor Vehicle Emissions}

Motor vehicle emissions account for about 90 percent of total emissions of hydrocarbons (smog), aldehydes, and carbon monoxide.

Economic factors that have led to increased vehicle emissions include the growth in population and disposable income, the mass production of affordable vehicles, the deterioration of alternate modes of transportation, and the need to travel longer travel distances as a result of urban sprawl have led to the increase in vehicle emissions. Although petrol prices are high, encouraging fuel efficiency, car owners are for the most part unable to respond to the incentive to conserve gas because of the lack of alternatives: maintenance and tune-up facilities and public transportation are inadequate, and cleaner or less expensive fuels have only recently been available in Pakistan. A subsidy on diesel fuel provides incentives to switch consumption to diesel, which is more polluting than many alternative energy sources.

Targeted policies have been introduced in Pakistan, but are ineffective because of institutional failures. For instance, restrictions are placed on vehicle emissions under the 1965 Motor Vehicle Ordinance and 1969 Motor Vehicles Act. However, even the rudimentary compliance with these laws is not enforced in any meaningful way. Regulations go unenforced because of difficulties monitoring compliance, because of lack of resources, and because of corruption. A new enforcement strategy must therefore propose institutional reform of the legal, administrative, and police departments.

The absence of emissions regulations, the lack of enforcement of motor vehicle fitness regulations, and owners' lack of capital to purchase replacements mean that old vehicles stay on the roads longer. The results is that the average vehicle in Pakistan emits 20 times more hydrocarbons, 25 times more carbon monoxide, and 3.6 times more nitrous oxides than the average vehicle in the United States.

A start has been made in providing better vehicle maintenance facilities to the driving public through the GEF-funded fuel efficiency improvement programme, which will set up modern gasoline and diesel engine diagnostic and tune-up centres in major urban centres in Pakistan. The project seeks to demonstrate the economic viability of such technology in the hope that such centres will be set up throughout the country. Immediate attention also needs to be paid to expanding and improving the public transportation system, currently patronised by only the lowest income groups; improving intercity railways; and enforcing regulations on excessive emissions from vehicles in all category groups. 


\section{Urban and Industrial Air Pollution}

Industry indiscriminately releases carcinogens (such as asbestos and soot), radioactive substances arising from nuclear waste and other manufacturing, and particulate matter and noxious fumes (such as carbon monoxide, sulfur dioxide, and hydrogen sulfide) into the air, and air quality is declining. A 1985 survey found that only 3 percent of industrial plants in Pakistan treated their wastes according to commonly accepted international standards.

Air pollution primarily affects urban areas, where the density of industry and vehicles prevents pollutants from being dispersed. Urban air pollution consists of particulate, sulfur dioxide, carbon monoxide, nitrogen dioxide, ozone, hydrocarbons, and heavy metals (such as lead).

Economy-wide policy failures are directly related to air pollution. Air typically becomes polluted because the social costs of emissions are not fully taken into account by decision-makers motivated by private profit, and because state enterprises, which may not be profit maximising, fail to internalise the environment. As was the case for industrial and urban waste water problems, such market failure suggests a need for government intervention through targeted environmental policies.

Retail prices to households for nontradable energy products, such as electricity and natural gas, remain below the economic cost of supply.

Several incentive-based approaches that have been used effectively in other countries-including emissions taxes, tradable pollution permits, and economic incentives for industries to acquire environment-friendly technology-have not been tried in Pakistan. Instead, the government has relied on regulatory approaches, which can be effective only if they are adequately monitored and enforced.

\section{Marine and Coastal Zone Pollution}

The coastal environment has changed over time, partly as a result of the massive take-off from the Indus River for irrigation and extensive pollution, particularly around the Karachi area. Most striking is the reduction in the mangrove forests, which has adversely affected fish and shellfish nurseries. Construction of barrages has reduced the size of fish catches and reduced the sediment load reaching the ocean, causing coastal erosion.

For the most part, marine and coastal zone pollution in Pakistan is limited to Karachi, a city of 8 million people that accounts for about 45 percent of the country's industry. All of Karachi's industrial waste, effluents, and domestic sewage, and all of the agricultural run-off from the hinterland and the Indus River find their way, untreated, into the sea.

Oil pollution is also a problem: of the 4 million tons of oil imported in 1986, 20,000 tons are believed to have leaked into coastal waters. 
Many marine and coastal zone problems can be associated with the absence or inappropriateness of policy. Waste water from industrial and domestic sources and agricultural run-off eventually end up in the river systems and ultimately in the sea. As a result, the economic policy failures that have led to industrial and domestic waste water have also caused coastal zone problems. No incentive- or market-based policies specifically address problems of marine and coastal zone pollution; only regulatory approaches have been used, and enforcement has been weak.

\section{MAJOR GREEN PROBLEMS AND THEIR CAUSES}

Pakistan contains at least six major natural resource systems: irrigated agriculture; rainfed, or barani agriculture; forests; rangeland; fisheries; and systems focused on preserving biodiversity (wildlife). Each system has different resource management and conservation problems. ${ }^{2}$ The area affected and the estimated production loss for each major problem are shown in Tables 2 and 3.

Table 2

Estimated Annual Losses Resulting from Natural Resource Degradation, 1988

\begin{tabular}{lcc}
\hline Problem & $\begin{array}{c}\text { Percentage of Area } \\
\text { Affected }\end{array}$ & $\begin{array}{c}\text { Annual Loss } \\
\text { (Millions of Dollars) }\end{array}$ \\
\hline Soil Degradation & - & 350 \\
Salinity and Sodicity & 16 & 213 \\
Waterlogging & 9 & 79 \\
Erosion & 9 & 44 \\
Nutrient Depletion & 12 & 9 \\
Unclassified & - & 7 \\
Deforestation & 10 & 30 \\
Rangeland Degradation & - & 125 \\
Total & - & 515 \\
\hline
\end{tabular}

Table 3

Extent of Soil Degradation by Province, 1988

(Thousands of Hectares)

\begin{tabular}{lrrrrcr}
\hline & Punjab & Sindh & NWFP & Balochistan & Northern Areas & Pakistan \\
\hline Total Area Surveyed & 20,625 & 9,222 & 9,139 & 19,141 & 3,685 & 61,812 \\
Water Erosion & 1,904 & 59 & 4,282 & 2,635 & 2,282 & 11,172 \\
Wind Erosion & 3,804 & 639 & 36 & 280 & - & 4,760 \\
Salinity and Sodicity & 2,667 & 2,110 & 48 & 502 & - & 5,328 \\
Waterlogging & 696 & 625 & 92 & 142 & - & 1,554 \\
Nutrient Degradation & 1,580 & 246 & 296 & 96 & - & 2,218 \\
Flooding & 915 & 763 & 276 & 598 & 5 & 2,557 \\
Ponding & 691 & - & 245 & - & - & 936 \\
\hline
\end{tabular}

Source: Mian and Mirza (1993).

- Not available.

study.

${ }^{2}$ In order to focus on the other major systems, fisheries and wildlife have been excluded from this 


\section{Irrigated Agriculture}

Eighty percent of Pakistan's cultivated area, or 17 million hectares, is irrigated, and irrigated agricultural accounts for more than 90 percent of agricultural output and 22 percent of national GDP. Pakistan has the largest contiguous canal irrigation system in the world, with over 1.6 million kilometers of canals, branches, distributaries, field channels, and watercourses. Forty percent of the total water supply is lost in the canals and watercourses before reaching the farm gate. Total availability of irrigation water at the farm gate is estimated at 105 million acre feet, of which 60 percent is supplied by canals, 35 percent by the more than 300,000 private tubewells, and the remaining 5 percent by public tubewells [Mohtadullah, Rehman, and Munir (1992)]. Most of the system is unlined, however, and since the 1970s water from private tubewells has accounted for a growing share of total water supplies. In many regions of the central Punjab as much as 70 percent of irrigation is supplied by tubewells, particularly in the rabi season.

In the 1950s and 1960s, waterlogging and salinity posed major hazards for irrigated agriculture. In most areas, the threat of waterlogging has receded since the 1970s, when the Salinity Control and Reclamation Project (SCARP) tubewells were installed and drainage was improved. The problem of salinity has become more acute in recent years, however, as a result of increased tapping of brackish groundwater for irrigation, and salinity poses the greatest danger to Pakistan's most important natural resource.

\section{Waterlogging, Salinity, and Ground-water Management}

Salinity is partly the result of naturally occurring geological processes and depends on the soil material, landform, relief, climate, and land use. In Pakistan, salinity has almost certainly increased as a result of the canal irrigation system as water containing dissolved salts from the lower parts of the soil profile seep from the canal system, and evaporate from the surface of adjoining soils. WAPDA has estimated that 2.12 million hectares of land are waterlogged, and Sandhu (1993) estimates that an additional 40,000 hectares per year are lost to waterlogging. These reports are based on outdated information; regular monitoring of waterlogging and salinity using standardised assessment criteria is needed so that more accurate estimates can be made.

The most neglected problem is that of tertiary salinity from the low-quality groundwater provided by tubewells. Surveys have shown that three-fourths of tubewells provide brackish water that is unfit or only marginally fit for agriculture. The cost of salinity in terms of reduced yields is hard to evaluate. Using farm-level data, Siddiq (1994) estimated that yield losses in wheat as a result of sodic irrigation water were 9 percent and 20 percent in two different locales in the central Punjab. 
Other experts have estimated that crop yields are reduced by about one-third for crops grown on slightly saline areas and that yields on moderately affected areas are reduced by about two-thirds. Crop production of any kind is difficult on highly saline soils.

Much of the problem of salinity caused by low-quality tubewell water can be reduced through the use of gypsum, and the government has tried to popularise gypsum use by farmers through provision of a sizeable subsidy. A similar programme was very successful in the Indian Punjab, where the problem of salinity has been drastically reduced through the use of subsidised gypsum. There are no data on the effects of the Pakistani programme. Field experience indicates, however, that in most instances, influential farmers appear to be the main beneficiaries of the subsidies.

Concerns about groundwater quality have been raised repeatedly over the past three decades but little effort has been made-by the provincial or the federal government, or by any of the multilateral aid agencies that invest heavily in the irrigation sector of the Indus Basin during the 1960s and 1970s-to monitor the effects of salinity of groundwater on soil resources and crop productivity. In the absence of a public agency with an official mandate to monitor the effects of salinity, provincial irrigation departments should be legally mandated to do so.

A critical issue in any discussion of salinity and waterlogging is the effect of water pricing policy on the efficiency and use of water. The subsidy on canal water has been substantial in recent years, accounting for more than 50 percent of the subsidy on operation and maintenance costs; the subsidy is much higher if measured in terms of the opportunity cost of water or against the cost of tubewell water. The underpricing of water and the basing of charges on the area irrigated in a season rather than on the quantity of water applied eliminates incentives to use water efficiently and has aggravated waterlogging and salinity [Ahmad and Kutcher (1992)]. The structure of water pricing provides no incentives for using canal water efficiently, and discourages investments in water conservation, such as drip or sprinkler irrigation systems [Noman (1994)]. All of these problems are linked to the lack of property rights on canal water. Although some canal water is unofficially exchanged and traded, rights to canal water are not officially recognised and there is no well-developed market to allocate canal water to its most efficient uses.

Use of tubewell water is also distorted by economic policy. Tubewell drilling and electricity are subsidised, and electricity prices for tubewells are based on the area irrigated in a season regardless of the volume used. Although tubewell water is widely traded at a price several times higher than that of canal water, there are no restrictions on the drilling of tubewells. In areas of limited groundwater, this means that there is no way of regulating or influencing through property rights the overexploitation of groundwater. One area of the country where this problem is particularly severe is in Balochistan. 
On the output side, prices of major crops continue to be distorted through trade policy and price supports. Domestic sugar prices, for example, have regularly been set above import prices, encouraging the domestic production of sugar, a crop with high water requirements. Factor price distortions that artificially encourage capital intensive techniques lead to the adoption of production methods that do not reflect factor endowments [Noman (1994)]. Subsidies or targeted credit for tractors and threshers have displaced labour, for example. The resulting environmental stress can be alleviated by providing more rural employment by removing the policy induced distortions in favour of highly capital intensive methods. Employment creation may also be the most effective strategy for reducing pressure on fragile soils in the mountain areas of northern Pakistan.

Resolution of the environmental problems facing Pakistan's water resources requires the implementation of fundamental changes in water pricing and in institutional structures to improve the efficiency of allocating water and maintenance. Radical new institutional structures have been proposed, including the devolution of water management to farmers organisations, and the establishment of public utilities to operate and price water further up the system [Ahmad and Faruqee (1995)].

\section{Other Soil Productivity Problems}

The mining of soil nutrients associated with a decline in organic matter and the extraction of other nutrients at a rate greater than their replacement through additions of inorganic and organic sources of nutrients threaten the sustainability of irrigated areas in Pakistan. In much of the irrigated area, farmers plant a single rotation, such as rice-wheat, without introducing a rotation crop or using organic manures. Indeed, there is evidence that cropping patterns have become less diverse as the area of fodder crops and pulses has fallen. Declining organic matter and declining yields for the same input level have been found in on-farm trials of the Soil Fertility Institute in the Punjab. Intensive monocropped agriculture may also be causing other as yet unrecognised soil problems.

With the removal of fertiliser subsidies, the need to promote organic sources of nutrients through farmyard and green manures, to diversify rotations to include legumes, and to employ other environment-friendly practices, such as conservation tillage, has grown. The Pakistan Agricultural Research Council has only very recently initiated a bio-organic approach to agriculture that emphasises organic sources of nutrients, including green manures, farmyard manure, composting, and microbiological approaches. Although these technologies are being extended, little research has been done on back up, especially on the fine tuning of these technologies needed to take account of the socioeconomic situations of small farmers. More research, especially participatory research with farmers, must be undertaken to develop appropriate methods for integrated nutrient management. 


\section{Pollution from Agricultural Chemicals}

The indiscriminate use of agricultural chemicals, such as fertilisers and pesticides, has contaminated ground- and surface water.

Agricultural chemical use in Pakistan's irrigated agriculture has expanded rapidly over the past twenty years. The most serious agricultural chemical problem stem from the rapid increase in pesticide use, from less than 1,000 tons in 1980 to more than 20,000 tons in 1995.

The widespread use of often dangerous pesticides on the cotton crop is associated with several potential health hazards, including contamination of workers who apply it (three quarters of producers use a back-pack sprayer and no protective clothing), harvesters (all of whom are women), soil and groundwater used for drinking, and consumers of agricultural products.

The exclusive reliance on pesticides to reduce pest losses is unsustainable as pest populations change and some pests develop resistance to commonly used pesticides. Resistance to pesticides has caused the cotton crisis of the past two years, in which losses from curl-leaf virus have sharply reduced the cotton harvest and even threatened supplies to the domestic textile industry. Short-run success in increasing cotton production over the past decade has come at the price of long-run sustainability.

Integrated pest management (IPM) is widely advocated as a means of reducing pesticide use and developing more sustainable production systems through the employment of a range of practices to combat pest populations. Despite the magnitude of the environmental and health problems associated with high levels of pesticide use on some crops, Pakistan has been a latecomer to the practice of IPM, and has been reactive rather than proactive. IPM is a knowledge-intensive practice that requires good extension service and is facilitated by literate farmers. Both are deficient in Pakistan and unless major emphasis is placed on promoting IPM it will be decades before pesticide use is reduced significantly.

\section{Rainfed (Barani) Agriculture}

About 20 percent, or 4.3 million hectares, of the total cultivated area in Pakistan is rainfed (barani). Rainfed agriculture is particularly important in northern Punjab and NWFP. Many of the natural resource issues affecting irrigated areas, particularly the use of agrochemicals and the decline in soil productivity, also affect rainfed areas, although usually to a lesser degree.

The major problem in rainfed areas is soil erosion, which has worsened over the years as population pressure, poverty, and stagnant yields have forced more people onto marginal areas to meet food, fodder, and fuelwood needs. Water erosion is the major cause of soil erosion in rainfed areas. About 11 million hectares 
of land are slightly or severely affected by water erosion problem in Pakistan, particularly in NWFP, where one-third of rainfed area is classified as seriously affected by water erosion.

Removal of vegetative cover for forage and fuel; loosening of previously stabilised loess surfaces in an effort to bring more land under cultivation; repeated shallow mechanised tillage, encouraged by cheap credit for tractor purchases, that has created a hard pan beneath the top soil restricting moister infiltration and inducing rainfall runoff; inappropriate terracing and ineffective field embankments allowing mud slides and torrential flows; and lack of crop cover as a result of bare following, removal of organic matter, and rodent damage aggravate the problem of rainfall run-off [Mian and Mirza (1993)].

Water erosion has serious environmental consequences in both the short and long term, include a continued decrease in the depth, fertility, and extent of productive soils; a decrease in agricultural production; continued deterioration of rangelands and forests reserves; increased rates of sedimentation in water reservoirs and channels, affecting their maintenance cost and life span; and adverse effects on the transportation infrastructure (roads, railways, bridges).

Soil erosion by wind is predominant in the sandy arid areas of Pakistan, mainly in the Thal and Cholistan Deserts in the Punjab, the Thar Desert in the Sindh, and the Kharan Desert in Balochistan, and depends on the nature of the soil, the wind velocity, the soil moisture, and the land relief. Dry fallow fields, saline soil surfaces, and loose dust in village and town streets supply large amounts of material that is transported to distant places by winds. Like water erosion, wind erosion occurs naturally but has been exacerbated by development activities.

Policies have provided incentives for farmers to cultivate more land to intensify their production practices, thereby exacerbating the rate of soil damage and degradation. Much of the emphasis on controlling soil erosion has been through engineering solutions in the form of contours, bunds, and check dams, usually implemented through programmes of the Ministry of Agriculture. Less emphasis has been placed on biological solutions involving cropping patterns to increase soil cover, conservation tillage, and use of vegetative contours and barriers. The National Agricultural Research Council is now testing such approaches in a pilot programme. The appropriate merging of engineering and biological solutions will require substantial participatory research and strong linkages between research and development. Community-based approaches are also needed.

\section{Forests}

Forests occupy only about 5 percent of the land area in Pakistan, and only one-third of the forests are productive in terms of timber extraction. Forests nevertheless plays an essential role in the country's economy because of their 
importance as sources of fuelwood and grazing land. Almost a third of the nation's energy needs are met by fuelwood, and forests are used for grazing a third of the country's livestock. Catchment forests prolong the lives of the Tarbela and Mangla reservoirs, which are vital for generation of hydroelectric power and regulating water supply to the largest irrigation system in the world.

Over 4.2 million hectares of natural forests, of which 1.9 million hectares is coniferous forest are confined mainly to the northern hilly areas of Pakistan. Scrub forests, riverine forests, and mangrove forests are found in the Punjab and the Sindh. Planted forests include irrigated plantations, riverine forests, linear plantations along roads and canals, and farm trees (trees raised on agricultural farms). Farm forestry represents the largest source of wood, contributing more than 50 percent of total annual growth, 80 percent of timber, and 90 percent of fuelwood harvested in Pakistan.

Deforestation leads to water erosion, which causes soil losses, siltation of reservoirs, and inefficiency in the irrigation system. This problem is most severe in the northern valleys, where migratory herdsmen and residents of the area have caused substantial destruction.

Establishing policies that do not distort the value of alternative uses for forest areas is also important. Artificially maintaining high agricultural output prices and low input prices, for example, increases the attractiveness of agricultural production and encourages the conversion of forests into farm land. Institutions are also required to increase awareness of sustainable development of forest resources. Forestry extension needs to be restructured and forestry products marketing boards need to be established.

Government policies have provided disincentives for afforestation. The sapling subsidy, for example, which was designed to create incentives to plant trees, crowded out provision of saplings by the private sector, limiting the overall supply of saplings available to producers. Because of this problem, a recent report recommended that the subsidy be eliminated [Faruqee (1995)].

Deforestation is also the result of poor forest management. Most natural forests are classified as state forests and the protection, timber extraction, and reforestation of these forests is vested in the Forest Departments. Revenues generated from timber sales are credited to the Treasury, however, and the departments responsible for forest management receive operational funds through annual budget appropriations that cover only a fraction of their requirements. As a result, needed replanting and maintenance are not carried out, resulting in deforestation and deterioration of the existing forests. Local communities have traditional rights in state forests, which increases pressure on forest resources as the population grows. Deforestation also takes place indirectly when regeneration efforts fail because of excessive grazing and inefficient supervision. 
The role of local communities in managing forest resources should be expanded. Traditionally local communities have not been consulted in forest management decisions and forest revenues have not been shared with local residents. Projects in NWFP have successfully demonstrated that communities can effectively protect forests and manage communal lands, however.

\section{Rangeland}

Most of Pakistan-30 million hectares, or 86 percent of the total area-is covered by rangeland, 80 percent of which is believed to be degraded. Much of the rangeland is threatened by overstocking, overgrazing, and overharvesting of the natural vegetation; and many of the ranges in Pakistan are populated by more animals (mostly sheep and goats) and people than they can support. Rangeland is damaged by deterioration and degradation. Range deterioration is caused mainly by climatic events, such as droughts. Losses are temporary and the productivity of the rangeland is renewed when more favourable climatic conditions return. Range degradation occurs when land becomes less productive because of mismanagement during drought years. Measures such as reducing stocking and frequencies until regrowth of palatable species reaches acceptable levels are required to remedy the condition; the return to more favourable climatic considerations is insufficient to restore the range.

In some parts of Pakistan, rangeland has become so badly degraded that the vegetative cover has become inedible or has disappeared altogether. Soil damage is a problem on such lands and degradation is so extensive that significant economic investment is required to restore productivity. Rangeland degradation is extensive in Balochistan, where two-thirds of all rangeland is classified as having low productivity and most of the damage is believed to be irreversible damage leading to desertification.

Most of the rangeland in Pakistan is either privately or tribally owned, or has open access; about 2 percent of rangeland is publicly owned. Population pressure, changing socials structures, and commercialisation of livestock enterprises have caused traditional tribal systems for controlling grazing to break down, leading to overgrazing and severe overstocking.

Failure to reduce the livestock population may be related to government policies that ban the export of meat and live animals in order to maintain the domestic price below international levels to subsidise domestic consumption. This has created incentives to overstock in defiance of communal pressures not to overgraze. Improvement of livestock productivity through improved veterinary services and extension should accompany any efforts to reduce livestock numbers. Research the technical, social, and institutional aspects of range management will be an important part of developing sustainable solutions to rangeland degradation. 


\section{CONCLUSIONS}

Economic policies that help eliminate market distortions generally stimulate growth and improve the environment. Many of Pakistan's environmental problems can be associated with economy-wide policies that have had indirect and unintended effects on the environment. Although some progress has been made at identifying the major environmental problems and their causes, and institutions have been established to tackle at least parts of the problems identified, recently progress has faltered. Environmental institutions have failed to fully monitor and regulate natural resource use and pollution adequately. According to government officials and local experts, progress has slowed largely because of the incentive structures created by existing policies and institutions. Economy-wide policies have discouraged conservation and pollution prevention, while the regulatory structure has failed because of inadequate enforcement and monitoring capability.

Through its structural adjustment programme, Pakistan has made some beginning in introducing win-win policies, including privatisation, trade reforms, and market liberalisation, and these policies should be continued and strengthened. Such policies are not sufficient to ensure sustainable resource use, however, and additional policies targeted at specific environmental problems are also needed. Environment-friendly policies, such as the tax on industrial pollution, need to be adopted to ensure that the improved economic incentives do not conflict with the need to use natural resources in ways that are sustainable. In short, government in the future should not rely exclusively on regulation, and increasingly adopt marketbased approaches, which can be more effective.

\section{REFERENCES}

Ahmad, M., and R. Faruqee (1995) Future of Irrigation in Pakistan. Paper presented at the Conference on Privatisation of Agricultural Services. Lahore University of Management Sciences, Pakistan, October 29-30. Washington, D. C.: World Bank.

Ahmad, M., and G. P. Kutcher (1992) Irrigation Planning with Environmental Considerations. A Case Study of Pakistan's Indus Basin. Washington, D. C.: (World Bank Technical Paper 166.)

Brandon, C. (1995) Valuing Environmental Costs in Pakistan. The Economy-wide Impact of Environmental Degradation. Unpublished background paper for Pakistan 2010 Report. Washington, D. C.: World Bank, Asia Technical Department.

Faruqee, R. (1995) Structural and Policy Reforms for Agricultural Growth. The Case of Pakistan. Washington, D. C.: The World Bank, South Asia Department 1, Agriculture and Natural Resource Division. 
Mian, A., and M. Y. J. Mirza (1993) Pakistan's Soil Resources. Government of Pakistan, Environment and Urban Affairs Division, in collaboration with the World Conservation Union, Islamabad. (Pakistan National Conservation Strategy Sector Paper 4.)

Mohtadullah, K., C. Ata-ur-Rehman, and C. M. Munir (1992) Water for the TwentyFirst Century. Government of Pakistan, Environment and Urban Affairs Division, in collaboration with the World Conservation Union, Islamabad. (Pakistan National Conservation Strategy Sector Paper 3.)

Munasinghe, M. (1993) Environmental Economics and Sustainable Development. Washington, D. C.: (World Bank Environmental Paper 3.)

Noman, O. (1988) The Political Economy of Pakistan, 1947-85. London: KPI.

Noman, O. (1994) Sustainable Agricultural Development in Pakistan. What Does it Mean and How Can it Be Implemented? Unpublished background paper for Agricultural Sector Study. Washington, D. C.: The World Bank, South Asia Department 1, Agriculture and Natural Resource Division.

Sandhu, G. R. (1993) Sustainable Agriculture. Government of Pakistan, Environment and Urban Affairs Division, in collaboration with the World Conservation Union, Islamabad. (Pakistan National Conservation Strategy Sector Paper 3.)

Shafik, N., and S. Bandyopadhyay (1992) Economic Growth and Environmental Quality. Time Series and Cross-sectional Evidence. Washington, D. C.: (World Bank Policy Research Working Paper 904.)

Siddiq, A. (1994) Sustainability of the Indus Basin Impact on Tertiary Salinity/Sodicity on Wheat Productivity: Damage Assessment and Future Public Policy. Ph.D. diss., University of Illinois, Urbana-Campaign, Department of Agricultural Economics.

World Bank (1994) Economy-wide Policies and the Environment: Emerging Lessons from Experience. Washington, D. C.: World Bank.

World Bank (1994a) Pakistan Irrigation and Drainage: Issues and Options. Washington, D. C.: World Bank. (Report No. 11884-Pak.)

World Bank (1995) Pakistan Energy Options Study. Washington, D. C.: World Bank. (Report No. 14025-Pak.) 


\section{Comments}

This is an important topical study which explores the inter-relationships between various economic policy instruments and economic growth and environmental degradation. Such studies can be quite helpful in devising better policies for sustainable long-run growth of the economy provided they clearly bring out the trade-offs between growth and environments. Unfortunately, the analysis presented in the study is at times vague and thus lessens the utility of the study considerably.

The basic thesis here is that market-friendly policies would improve the environment. This is notwithstanding the fact that it is the market failure which gives rise to the environmental problems. Whenever there is a difference between social and economic profitability, market prices result in sub-optimal solutions because the externalities are not internalised.

A number of measures suggested in the study for environmental protection may result in higher levels of poverty, which feeds into environmental degradation. The structural adjustment programmes at least in the transitional period result into higher levels of poverty, which is the main cause of environmental degradation. Devaluation which is generally recommended in all such programmes, has, in the author's view, improved the environment by changing the use of chemical fertilisers. One is at a loss to know if the author is suggesting that a lower use of fertiliser (and that too through devaluation) is necessary and sufficient for better environment. The study appreciates the increase in the prices of pesticides and insecticides but fails to analyse if the withdrawal of subsidy has helped the environment. Moreover, the impact of increase in the prices of agricultural inputs on poverty, and resultantly environmental degradation, has not been considered either.

It is mentioned that energy use is subsidised in Pakistan and that undermines the incentives for energy conservation. This is contrary to the fact because except for the electricity and gas (and that too for very poor consumers), energy is not subsidised. Removal of subsidy to the poor will increase poverty and thus aggravate the problem of environment even further. Increase in the price of gas will shift the consumption towards coal or firewood, accentuating the environment problems.

Low water pricing may result in waterlogging and salinity through excessive use of water. However, an improvement in the distribution system, rather than just an increase in the prices, will have the desirable impact. The study also points out the areas affected and the annual loss due to soil degradation, deforestation, rangeland degradation, etc. It would have been desirable if, alongwith the losses, the cost of avoiding the loss was also mentioned. This would underscore the effectiveness of the resources employed in such activities. 
The paper includes an interesting discussion on international trade and the Uruguay Round and suggests that international trade would promote environmentfriendly technologies. But why such a result may be expected is not very clear from the analysis.

Privatisation has also been suggested as a way to promote environmentfriendly techniques. One wonders how this policy would help in improvements in environment; while the government may be able to force the public sector industries to use environment-friendly techniques, the private sector may have to be regulated or persuaded to use such techniques.

The main contribution made by the author has been to put the policy areas and instruments in the context of their environmental impact. However, the policy matrix does not indicate clearly the direction in which the environment would move. Similarly it would have been much better to come up with those measures where both growth and environment are complementary.

The author mentions that most of the technologies used in Pakistani industries are those which were acquired when energy prices were artificially low. This is probably not correct. The industries mentioned in the study such as textiles, fertiliser, sugar, and cement have received massive dozes of investment in recent years. Probably what needs to be seen is whether the new investment incorporates environment-friendly techniques or not. No doubt, there exist environment-friendly techniques but whether the producers have any incentives to switch over to new techniques needs to be examined. In Pakistan, even the multinationals do not have any treatment plants.

The author points out that over the 1963-1988 period the level of pollution increased between $6-10$-fold even though recent data are not available. How these estimates were obtained and what data were required to update the estimates has not been discussed. Interestingly, the author talks about the average emissions in Pakistan as compared to the United States but fails to provide data on other developing countries.

All in all, the paper provides interesting data and information but more work needs to be done if such an analysis has to form the basis for any policy formulation.

Planning and Development Division,

A. R. Kemal

Government of Pakistan,

Islamabad. 